\title{
Zdzisława Orłowska-Popek, Emocje w wypowiedziach uczniów niestyszących, Wydawnictwo Naukowe Uniwersytetu Pedagogicznego, Kraków 2011, ss. 274
}

Książkę Zdzisławy Orłowskiej-Popek uznać trzeba bez wattpienia za interesującą $\mathrm{i}$ bardzo potrzebna. Jest to opracowanie dotykające ważnego problemu kompetencji językowej (leksykalnej) osób z dysfunkcją narządu słuchu. Badania w tym zakresie prowadzone są obecnie z coraz większym impetem.

Opracowanie składa się z pięciu rozdziałów (s. 8-260) i obudowy, którą tworzą: wstęp (s. 5-7), bibliografia (s. 261-273) oraz spis tabel (s. 274-275).

Przedmiotem szczegółowych eksploracji jest słownictwo związane z emocjami, którym posługują się niesłyszący uczniowie szkół specjalnych oraz klas integracyjnych w szkołach powszechnych. Cel opracowania autorka formułuje następująco: „Celem badań było ukazanie specyfiki języka opisującego emocje uczniów niesłyszących oraz wskazanie optymalnych strategii nauczania «języka uczuć»». Jak wynika z obserwacji [, - P.W.] umiejętność werbalizowania stanów psychicznych u większości niesłyszących uczniów szkół specjalnych jest niewspółmierna do ich rozwoju emocjonalnego. Jednak zasób środków leksykalnych, jakimi dysponują, nie wystarcza, by skutecznie, precyzyjnie i stosownie do sytuacji komunikacyjnej mówić o uczuciach. Stąd podjęłam próbę ustalenia zasobu słownictwa nazywającego uczucia w języku niesłyszących uczniów gimnazjum i liceum. Najbardziej interesowały mnie leksemy służące jawnemu uzewnętrznianiu przeżyć (rzeczowniki, czasowniki, przymiotniki, przysłówki), a wśród nich szczególnie użycie przymiotników. Zwróciłam też uwagę na posługiwanie się przez osoby z uszkodzonym słuchem wykrzyknikami, wyrażeniami dźwiękonaśladowczymi oraz leksemami metaforycznymi i frazeologizmami" (s. 5-6).

Autorka - co należy mocno podkreślić - nie poprzestała na opisie i interpretacji zaobserwowanych faktów językowych. Pokusiła się także o sfor- 
mułowanie wskazówek metodycznych dotyczących rozwijania kompetencji leksykalnej uczniów niesłyszących w zakresie słownictwa związanego z emocjami. Słuszność tej decyzji nie podlega dyskusji. Zwrócić jednak należy uwagę na pewną nieścisłość w deklaracji Zdzisławy Orłowskiej-Popek. Chodzi o pojemność znaczeniową określenia słownictwo nazywajace uczucia. Odnosi się ono przecież do jednostek (o różnym statusie formalnym) denotujących emocje, np.: cieszyć się, smucić, czuć obrzydzenie, lubić, nienawidzić, zmartwienie, szczęście, wstyd, żal, być rozgoryczonym, radość z czyjegoś nieszczęścia. W niektórych ujęciach zespół wymienionych elementów uzupełniają związki frazeologiczne odsyłające do typowych objawów emocji czy też zachowań, wyglądów osób, określonych sytuacji, które wiązane są (w świadomości użytkowników języka) z przeżyciami wewnętrznymi (np. $x$ zzieleniał ze złości, $x$-owi serce wali z radości, $x$ poczuł zimno na twarzy, $x$ rwie sobie włosy z głowy, $x$ trzęsie sie jak galareta). A zatem w grupie środków językowych nazywających emocje nie mieszczą się wskazywane w rozprawie wykrzykniki czy onomatopeje. Omawiany problem ściśle wiąże się z typologią ekspresji Stanisława Grabiasa, który na podstawie różnych kryteriów wyodrębnił przejawianie, wyrażanie i komunikowanie uczuć. Do wyrażania emocji służą struktury ekspresywne, w tym np. wspomniane przez Zdzisławę Orłowską-Popek wykrzykniki. Proces komunikowania przeżyć wewnętrznych opiera się z kolei na jednostkach leksykalno-frazeologicznych (również o charakterze metaforycznym) eksplicytnie określających doznania emocjonalne (także ich objawy), czyli elementach postrzeganych przez autorkę jako słownictwo nazywające uczucia i leksemy metaforyczne. Badaczka przywołuje w pracy koncepcję Stanisława Grabiasa, ale nie wykorzystuje jej podczas oglądu materiału badawczego, co skutkuje pewnym nieporządkiem w jego opisie i klasyfikacji.

Dane językowe stanowiące przedmiot analiz Zdzisława Orłowska-Popek uzyskała na podstawie przeprowadzonych badań eksperymentalnych wśród 41 osób: 30 uczniów z dwóch ośrodków szkolno-wychowawczych dla dzieci niesłyszących w Krakowie (siedmioro z pierwszej klasy gimnazjum, siedmioro z trzeciej klasy gimnazjum, szesnaścioro z pierwszej klasy liceum ogólnokształcącego) oraz 11 uczniów uczęszczających do małopolskich szkół integracyjnych. Jak informuje autorka, ,wszystkie badane osoby były ogłuchłe prelingwalnie, a ich ubytek słuchu wahał się w granicach 70-120 dB w paśmie mowy" (s. 42). Należy w tym miejscu zaznaczyć, że pasmo mowy osiaga poziom ciśnienia akustycznego w zakresie najwyżej do $90 \mathrm{~dB}$. Osoba z ubytkiem słuchu osiagającym $100 \mathrm{~dB}$ cierpi na głuchotę totalną. W tym kontekście podawany przez badaczkę przedział dotyczący ubytku słuchu jest całkowicie niezrozumiały. Zdziwienie wywołuje również sens kolejnego zdania autorki: 
„Badani używali aparatów słuchowych zausznych, które jednak nie umożliwiały odbioru mowy drogą słuchową" (s. 42).

Zadania przygotowane przez Zdzisławę Orłowską-Popek miały sprawdzić umiejętność posługiwania się przez uczniów przymiotnikami wartościującymi oraz zdolność werbalnej deskrypcji emocji. Badani zostali poproszeni o wykonanie siedmiu poleceń (zapisanych na tablicy i odpowiednio skomentowanych), które polegały kolejno na: 1) doborze przymiotników (przydawek) do podanych rzeczowników (mama, szkoła, pani, ksiqżka, wycieczka, wakacje), 2) dopisywaniu rzeczowników do podanych przymiotników (dobry, zły, miły, ładny, wesoły, szczęśliwy, brzydki, grzeczny, madry, smutny, kochany, niegrzeczny), 3) wypełnianiu luk w linearnej strukturze zdania (np. Byłam ..., bo dostałam piatke z matematyki), 4) tworzeniu przymiotników od podanych rzeczowników (szczęście, smutek, nieszczęście, radość), 5) odpowiadaniu na postawione pytania typu Co mówisz, kiedy...? (np. Co mówisz, kiedy wylałeś sok na biały obrus i mamie jest bardzo smutno?), 6) uzupełnianiu wypowiedziami dymków przyporządkowanych różnym postaciom umieszczonym na pięciu obrazkach sytuacyjnych (wykonanych w konwencji komiksu), 7) konstruowaniu tekstów na dwa tematy (Mała dziewczynka została sama w domu. Napisz, co robiła i jak się czuła oraz Pan Józek wygrał w Lotto milion złotych. Napisz, co robił i jak się czut).

Uzyskane w ten sposób dane autorka interpretuje w najobszerniejszej, centralnej części pracy (s. 50-237). Przywołuje w niej wypowiedzi wszystkich uczniów i obudowuje je odpowiednim komentarzem.

Na podstawie zgromadzonego materiału Zdzisława Orłowska-Popek dochodzi do silnie emocjonalnego wniosku, iż „wśród niesłyszących przeraża ubóstwo leksyki opisującej emocje" (s. 254). Szczegółowe porównania pozwoliły także zauważyć wyraźną dysproporcję w zakresie omawianej kompetencji leksykalnej między uczniami ze szkół specjalnych a uczniami z klas integracyjnych. Bardzo niski poziom znajomości słownictwa związanego z emocjami wykazują uczniowie ze szkół specjalnych. Fakt ten łączy autorka ze zbyt późno rozpoczętą terapią i nieodpowiednimi metodami kształcenia. Jak podkreśla, „uczniowie z uszkodzonym słuchem są zdolni do osiagnięcia wysokiej sprawności językowej, o czym świadczą teksty przygotowane przez badanych objętych wczesną terapią i w rezultacie uczęszczających do szkół powszechnych" (s. 238).

Recenzowana rozprawa ma przejrzystą, logiczną architektonikę (rozczłonowanie pionowe i poziome). Wattpliwości może jedynie budzić wyodrębnienie (i przy okazji niezbyt precyzyjnie sformułowany tytuł) szczupłego rozdziału Językowe sposoby określania emocji. Składają się nań dwa podrozdziały: Znaczenie przymiotnika $w$ języku (można by się zastanawiać nad 
trafnością takiej nazwy w kontekście poruszanych w podrozdziale zagadnień) oraz Wyrażanie emocji w aspekcie rozwoju języka. Oba problemy wiążą się ściśle z wcześniejszymi rozważaniami autorki podejmowanymi w rozdziale pierwszym (zob. podrozdział Sposoby wyrażania emocji), dlatego tam winny być - moim zdaniem - zaprezentowane.

Nie wszystkie komentarze badaczki dotyczące analizowanych wypowiedzi osób niesłyszących są wyczerpujące i bezdyskusyjne. Na przykład na s. 72 dopisaną przez uczennicę do rzeczownika pani formę denerwowana traktuje autorka wyłącznie jako zniekształcony (pozbawiony inicjalnej litery) wariant jednostki zdenerwowana. Nie można jednak wykluczyć interpretacji zakładającej iteratywność imiesłowu denerwowana. Słowo brzydki nie jest - jak chce badaczka - leksemem wartościującym konotacyjnie, lecz opisowo, a potoczny wyraz facet nie odznacza się negatywnym zabarwieniem ekspresywnym (s. 94). Sądzę, że zastosowana przez uczennicę forma ślepiona (Ania była ślepiona, bo zgubiła rękawiczki), której znaczenia nie udało się autorce odczytać, nawiązuje - a na taki wniosek pozwala kontekst syntagmatyczny - do przymiotnika ślepa (s. 108-109).

W niektórych analizach (ale także w rozdziale piątym podsumowującym wyniki badań) powraca problem kwalifikowania środków językowych jako nazywających uczucia. Autorka stawia - niesłusznie - znak równości między przymiotnikami wartościującymi a słownictwem nazywającym emocje. Zakresy obu tych zbiorów tylko częściowo na siebie zachodzą. Każde adiectivum denotujące uczucia waloryzuje (przy czym ocena ta może się odnosić do różnych aspektów sytuacji przeżywania emocji), ale nie każdy przymiotnik wartościujący nazywa uczucie. Elementy leksykalne typu niedobre (koledzy sq niedobre) czy łobuze ('łobuzy') (s. 163) emocji nie nazywaja, lecz je - ewentualnie - wyrażają (jeśli przyjać, że każdy akt wartościujący ma nacechowanie emotywne - takie ujęcie emotywności reprezentuje Elżbieta Laskowska; w innym wypadku przede wszystkim przymiotnik niedobre należałoby wykreślić z listy ekspresywizmów).

W jednym z opisów badaczka nie odnotowuje czasownika krzyczy, który w tekście sporządzonym przez uczennicę wskazuje na objawy emocji (s. 208). Z podobnymi przeoczeniami mamy do czynienia także w innych miejscach. $\mathrm{Na}$ przykład w uczniowskim komunikacie na s. 221 Zdzisława Orłowska-Popek nie zauważa konstrukcji werbalno-nominalnej jest dumny (oznaczającej pozytywne uczucie z klasy semantycznej dumy). Nieco wcześniej (s. 220) odnotowuje zwrot czuje się bogaty $i$ dumny, ale uznaje go za nieopisujący emocji. Na s. 222 nie pojawia się w uwagach autorki leksem płacze, który posłużył - jak należy domniemywać na podstawie całej wypowiedzi uczennicy - do określenia objawów negatywnych uczuć, a na s. 236 brak wskazania na połączenie 
bardzo się boi (z leksykalnym wykładnikiem natężenia emocji strachu). Na s. 245 nie uzasadnia autorka, dlaczego syntagmę $X$ czuje się bogaty traktuje jako informującą o przeżyciach wewnętrznych. $\mathrm{Z}$ kolei konstrukcje $X$ bardzo cieszy się czy $X$ denerwuje się nie wskazują na objawy uczuć, lecz te uczucia wprost nazywają (s. 245).

Niektóre wypowiedzi uczniowskie pozbawione są stosownego komentarza uwypuklającego struktury językowe decydujące o emocjonalnym zabarwieniu komunikatów. Ogranicza się wówczas badaczka do ogólnych stwierdzeń typu: „Wyglądają [teksty - P.W.] bardzo naturalnie, jak części dialogów prowadzonych w danych sytuacjach. Nie brak im także emocjonalnego charakteru” (s. 185), „W zapisanych przez uczennicę zdaniach malują się uczucia, bez których wypowiedzi byłyby martwe" (s. 198).

Zdzisława Orłowska-Popek w partiach wstępnych pracy uznaje synonimiczność jednostek uczucie i emocja. Niektóre użycia tych terminów przeczą takiemu stanowisku, np.: „Małe dziecko słyszące określa słowami swoje emocje i uczucia poprzez partykuły, wykrzykniki, zdrobnienia i zgrubienia" (s. 23), „Zadaniem uczniów było sporządzenie opisu przeżyć wewnętrznych, czyli uczuć, doznań, emocji, towarzyszących małej dziewczynce [...]” (s. 200). W wypadku ostatniego przykładu nasuwa się pytanie o relacje semantyczne między strukturami uczucie, doznanie, emocja.

Szkoda, że w trakcie redakcyjnego przygotowywania książki nie udało się uniknąć rozlicznych usterek. Razi ogromna liczba błędów interpunkcyjnych (nieoddzielanie przecinkiem zdań składowych, wtrąceń, nieuzasadnione użycie przecinka itp.). Oto zaledwie garść przykładów: „Wygląda to tak jakby Piotrek przeprowadził losowy wybór rzeczowników i zapisał je obok przymiotników" (s. 77), „Dwa użyte przez chłopca przymiotniki w dwóch ostatnich zdaniach, informują odbiorcę o uczuciach postaci [...]” (s. 108), „Wypowiedzenia, jakie utworzyła mają prawidłową konstrukcję [...]” (s. 123), „W ostatnim zdaniu zapisała formułę przeprosin umieszczając zdrobnienie zakomunikowała tym samym o swoim stosunku do zaistniałego zdarzenia” (s. 153), „W kilku zdaniach, można zauważyć różne błędy [...]” (s. 193-194), „W badanej wypowiedzi, brak jasnego podziału na zdania” (s. 204), „W pierwszym zdaniu, żeby pokazać zewnętrzne i wewnętrzne objawy odczuć autorka wykorzystała czasowniki [...]” (s. 232), „W kolejnej grupie znalazły się konstrukcje z czasownikami wskazującymi na zewnętrzne objawy uczuć, bądź też nazwy czynności świadczących o wewnętrznych przeżyciach [...]" (s. 241). Błędy interpunkcyjne występują ponadto $\mathrm{w}$ cytowanych przez autorkę fragmentach opracowań innych badaczy, które to fragmenty takich błędów nie zawierają (,S. Grabias (1981: 31) zauważa, że «emocjonalność nie dotyczy realności, lecz jest wyrazem tego czy nadawca uczuciowo akceptuje treść komunikatu, czy też nie, 
i wiąże się z wartościowaniem»", s. 237). Nagminnie stosuje autorka formę w przypadku (np. s. 76, 79, 88, 90, 94, 100, 129, 159, 184), nie unika potknięć typu: przy pomocy czegoś (np. s. 7, 21, 72, 137, 149, 150, 193, 215, 227), coś przyjmuje postać czegoś (s. 139), petnić role (s. 161). Z wyliczania innych usterek rezygnuję.

Ze względu na ważkie społecznie wyniki naukowe i zgłaszane postulaty książka Zdzisławy Orłowskiej-Popek winna stać się lekturą obowiązkową (czytana jednak krytycznie) nade wszystko dla nauczycieli pracujących z osobami niesłyszącymi, którzy odpowiadają za rozwój ich kompetencji językowej i komunikacyjnej.

Przemysław Wiatrowski 